\title{
KONSTRUKSI SOLIDARITAS SOSIAL BESIRU MASYARAKAT DI DESA SEMBALUN BUMBUNG
}

\author{
Siti Ilhami Fatmahandayani ${ }^{1}$,Peri Anggraeni ${ }^{2}$, Nurul Haromain $^{3}$ \\ Program Studi Sosiologi Universitas Mataram
}

\begin{abstract}
ABSTRAK
Masyarakat indonesia terkenal dengan sikap ramah, kekeluargaan dan kesetiakawanan memungkinkan lahirnya prinsip hidup bersama yang kemudian di sebut gotong royong. $\mathrm{Hal}$ ini menjadi penguat karakter bangsa. Gotong royong hidup dalam masyarakat yang dinamis, bersamanya masyarakat tertantang untuk mewariskan prinsip hidup dari generasi ke generasi. Namun, Kemajuan teknologi informasi menjadi suatu hal yang tidak dapat dihindari, arus globalisasi yang deras menawarkan gaya hidup yang cenderung pragmatis mengutamakan prinsip individualis, materialis serta gaya hidup konsumtif. Perlahan-lahan hal ini telah mereduksi nilai-nilai yang diajarkan dalam kearifan lokal. Pergeseran nilai akibat globalisasi bukan hanya menjadi tantangan tapi dapat menjadi ancaman pada perubahan karakter bangsa. Demikian pula pada masyarakat di Pulau Lombok, perkembangan teknologi global yang semakin pesat, kemajuan pariwisata dan menjamurnya pusat perbelanjaan modern memberikan dampak yang sangat signifikan dan cenderung berakibat pada tersingkirnya nilai-nilai kearifan lokal seperti budaya tolong menolong atau yang dikenal dengan budaya besiru pada masyarakat Lombok. Tujuan dari penelitian ini Untuk mengetahui masyarakat konstruksi sosial budaya besiru di Desa Sembalun Bumbung dengan metode penelitian kualitataif dan menggunakan analisa diskriptif. Hasil Penelitian pada masyarakat desa Sembalun bumbung mecerminkan kontruksi sosial solidaritas besiru yang didasari atas 3 landasan hidup masyarakat di desa sembalun bumbung.

Kata Kunci: Gotong royong, globalisasi, kearifan lokal, solidaritas besiru, sembalun bumbung
\end{abstract}

\section{ABSTRACT}

Indonesian society is well-known for its friendly attitude, kinship and solidarity, enabling the birth of the principle of living together which is then called mutual cooperation. This is a reinforcement of national character. Mutual cooperation lives in a dynamic society, with the community challenged to pass on the principle of life from generation to generation. However, the advancement of information technology has become an unavoidable thing, the rapid flow of globalization offers a lifestyle that tends to be pragmatic in prioritizing individualist, materialist and consumptive lifestyles. Slowly this has reduced the values taught in local wisdom. Shifting values due to globalization is not only a challenge but can be a threat to changes in national character. Likewise for the people on Lombok Island, the rapid development of global technology, the advancement of tourism and the proliferation of modern shopping centers have a very significant impact and tend to result in the elimination of local wisdom values such as helping culture or what is known as the culture of Lombok people. The purpose of this study was to find out the socio-cultural construction community besiru in Sembalun Bumbung Village with a qualitative research method and using descriptive analysis. The results of the research on the Sembalun bumbung village community reflect the solid construction of solidarity based on the 3 foundations of the community in the village of Sembalun Bumbung.

Keywords: Mutual cooperation, Globalization, local wisdom, Besiru Solidarity, Sembalun Bumbung. 


\section{PENDAHULUAN}

Masyarakat indonesia terkenal dengan sikap ramah, kekeluargaan dan kesetiakawanan memungkinkan lahirnya prinsip hidup bersama yang kemudian di sebut gotong royong. Hal ini menjadi penguat karakter bangsa. Gotong royong merupakan perwujudan sila pancasila yang mampu menciptakan solidaritas sosial, mempererat tali persaudaraan, menyadarkan masayarakat akan kepentingan umum dan tanggung jawab sosial, menciptakan kerukunan, toleransi yang tinggi serta rasa persatuan dalam masyarakat Indonesia. Gotong royong tidak sekedar menjadi prinsip tapi mampu menjadi spirit dan tata cara hidup bersama.

Gotong royong hidup dalam masyarakat yang dinamis, bersamanya masyarakat tertantang untuk mewariskan prinsip hidup ini dari generasi ke generasi. Selain itu, hal tersebut juga menjadi ancaman seiring derasnya arus globalisasi saat ini yang menimbulkan pengaruh negatif terhadap perkembangan budaya dan nilai-nilai kearifan lokal yang dimiliki bangsa indonesia. Kemajuan teknologi informasi dan globalisasi menjadi suatu hal yang tidak dapat dihindari, arus globalisasi yang deras menawarkan gaya hidup yang cenderung pragmatis yang mengutamakan prinsip individualis, materialis serta gaya hidup konsumtif. Perlahan-lahan hal ini telah mereduksi nilai-nilai yang diajarkan dalam kearifan lokal. Hal ini dibuktikan dalam penelitian Setiadi, E dan Kolip, U. (2011) mengemukakan bahwa masyarakat Indonesia dalam proses pembangunan di era globalisasi ini memiliki kecenderungan berupa merosotnya semangat gotong royong, tidak menghargai prestasi, menempuh jalan pintas, cenderung menyelematkan diri sendiri serta memiliki rasa solidaritas sosial dan semangat kedisiplinan yang menurun. Selain itu, diperkuat dari hasil penelitian yang dilakukan oleh Hamaidah (2002) di tujuh daerah di Jawa Timur menunjukkan adanya indikasi penurunan kepedulian sosial dan kepekaan terhadap orang lain banyak terjadi pada remaja yang nampak lebih mementingkan diri sendiri dan keberhasilannya tanpa mempertimbangkan keadaan orang lain di sekitarnya.

Pergeseran nilai akibat globalisasi ini bukan hanya menjadi tantangan tapi dapat menjadi ancaman pada perubahan karakter bangsa. Demikian pula pada masyarakat di Pulau Lombok, perkembangan teknologi global yang semakin pesat, kemajuan pariwisata dan menjamurnya pusat perbelanjaan modern memberikan dampak yang sangat signifikan dan cenderung berakibat pada tersingkirnya nilai-nilai kearifan lokal seperti budaya tolong menolong atau yang dikenal dengan budaya beseru pada masyarakat Lombok. Masyarakat Sembalun merupakan salah satu daerah di Pulau Lombok yang memiliki tingkat kepedulian dan tradisi kegotong royongan (besiru) semakin lama mengalami degradasi akibat dari kemajuan pariwisata dan ditetapkannya daerah ini sebagai the best halal tourism dan best honey moon yang membuat masyarakat terkontaminasi ke arah yang negatif. Namun, sebuah kejadian alam menjadi refleksi diri bagi masyarakat Lombok, kejadian alam gempa bumi berturut-turut dengan kekuatan 6,5 Skala Richter di daerah Sembalun, Lombok Timur serta dilanjutkan dengan gempa berkekuatan 7,0 Skala Richter di daerah Kabupaten Lombok Utara mengakibatkan pembangunan yang terjadi di Lombok menjadi lumpuh total dan 23.098 rumah rusak serta 466 Korban Meninggal dunia dengan kerugian mencapai 8,8 Triliun Rupiah mengingatkan masyarakat Lombok akan makna solidaritas yang telah memudar.

\section{Landasan Teori}

Peneliti menggunakan bantuan teori Peter L. Berger. Berger dengan konstruksi sosial berupaya untuk menjelaskan makna pengalaman hidup sejumlah orang tentang suatu gejala, termasuk didalamnya tentang pengaplikasian tindakan yang nantinya terkonstruksi dalam masyarakat melalui 
proses eksternalisasi,objektivasi dan internalisasi. Teori dari Berger relevan dengan permasalahan penelitian yang akan diteliti. Hal ini dikarenakan teori Berger dapat menjelaskan bagaimana konstruksi sosial masyarakat terhadap budaya beseru di Desa Sembalun Bumbung.

\section{METODE PENELITIAN}

Penelitian ini dirancang dengan menggunakan pendekatan kualitataif dengan menggunakan analisa diskriptif. Pendekatan kualitatif adalah suatu proses penelitian dan pemahaman yang berdasarkan pada metodologi yang menyelidiki suatu fenomena sosial dan masalah manusia. Peneliti membuat suatu gambaran kompleks, meneliti kata-kata, laporan terinci dari pandangan responden, dan melakukan situasi yang dialami. Bogdan dan Taylor mengemukakan bahwa metodologi kualitatif merupakan prosedur penelitian yang menghasilkan data deskriptif berupa katakata tertulis maupun lisan dan perilaku dari orang-orang yang diamati. Penelitian ini menggunakan studi atau metedologi fenomenologis. Menurut Peter L. Berger, studi fenomenologi dengan konstruksi sosial berupaya untuk menjelaskan makna pengalaman hidup sejumlah orang tentang suatu gejala, termasuk didalamnya tentang pengaplikasian tindakan yang nantinya terkonstruksi dalam masyarakat melalui proses eksternalisasi,objektivasi dan internalisasi. (Ritzer, 2004).

Data diperoleh dari penelitian yang dilakukan di Desa Sembalun Bumbung selama dua bulan dari bulan Februari sampai Maret. Peneliti mengunakan dua sumber data untuk mencari dan mengumpulkan sumber data dalam penelitian ini, dan hasil data yang akan diolah, yaitu (Sugiyono, 2007) Data primer adalah data yang diambil secara langsung oleh peneliti kepada sumbernya tanpa ada perantara. Peneliti mencari dan 43 menemukan data kepada informan baik wawancara maupun pengamatan langsung di lapangan. Kata-kata dan tindakan orang yang diamati atau diwawancarai merupakan sumber data yang utama (Moleong, LJ 2005: 157). Sumber data primer merupakan sumber data yang diperoleh dengan cara menggali sumber asli langsung dari informan, pencatatan sumber data utama melalui wawancara atau pengamatan diperoleh melalui hasil usaha gabungan dari kegiatan melihat, mendengarkan dan bertanya dan Data Sekunder Sumber data sekunder adalah sumber data tidak langsung yang mampu memberikan tambahan serta penguatan terhadap data penelitian. Sumber data dalam penelitan kualitatif ini selain berupa kata-kata, bahasa dan tindakan dari informan juga dapat diperoleh melalui studi kepustakaan dengan media buku dan media internet untuk mendukung analisis dan pembahasan. Selain itu juga akan mengambil data dari arsip-arsip dan foto-foto pada saat penelitian berlangsung. Agar penelitian ini dapat dipertanggungjawabkan, maka sumber data menjadi sangat penting sehingga akan didapatkan hasil penelitian yang benar-benar mendetail. Teknik pengumpulan data pada penelitian ini menggunakan teknik wawancara mendalam, observasi partisipatif, dan dokumentasi.

\section{HASIL PENELITIAN DAN PEMBAHASAN}

\section{a. Solidaritas Sosial Besiru pada masyarakat Sembalun Bumbung}

\section{a. Solidaritas Besiru}

Solidaritas sosial menurut Paul Johnson (1980:181) bahwa solidaritas menunjukkan pada suatu keadaan antar individu dan atau kelompok yang didasarkan perasaan moral dan kepercayaan yang dianut bersama, yang diperkuat oleh pengalaman emosional bersama. Sedangkan Solidaritas sosial menurut Robbert M.Z Lawang (1985:262), yaitu dasar 
pengertian solidaritas sosial tetap berpegang pada kesatuan, persahabatan, saling percaya yang muncul dari tanggung jawab dan kepentingan bersama diantara para anggota.

Lebih jelas tentang solidaritas di kemukakan oleh Emile Durkheim yang di kutip oleh Robbert M.Z Lawang (1985:63) bahwa solidaritas sosial adalah keadaan saling percaya antar anggota kelompok atau komunitas. Jika orang saling percaya mereka akan menjadi satu atau menjadi sahabat, menjadi saling menghormati, menjadi saling bertanggung jawab untuk saling membantu dalam memenuhi kebutuhan antar sesama.

Pada dasarnya Solidaritas merupakan suatu tindakan kemanusiaan yang didasarkan kepada rasa persatuan dan kesatuan dalam suatu masyarakat. Tindakan ini akan membentuk suatu proses saling membantu, saling percaya, saling memahami dan saling menghargai satu sama lain. Salah satu dari implementasi solidaritas sosial yaitu pada budaya besiru. Budaya besiru pada dasarnya merupakan suatu tindakan dalam membantu dan menolong orang lain.

Pada masyarakat Sasak khususnya di desa Sembalun, Besiru sering dilakukan dalam kegiatan membantu masyarakat khususnya pada bidang pertanian atau agraria. Besiru ini terus dilakukan sejak zaman Nenek moyang dan masih dilestarikan serta tertanam kuat dalam diri masyarakatnya hingga saat ini sebagaiamana ungkapan dari salah satu informan (Tokoh Agama)

" besiruan min sembalun khususna Desa Sembalun Bumbung nene uwah arak lekan ita masih jari angin sampai ningka masih tetep lestariang min masyarakat".

Artinya Besiruan telah ada di Desa Sembalun Bumbung ini sudah dari zaman dahulu bahkan sebelum saya lahir juga sudah ada dan tetap dilestarikan oleh masyarakat sampai sekarang.

Besiru jika diistilahkan menggunakan bahasa Indonesia adalah gotong royong atau saling balas (resiprositas) yang berarti masyarakat sembalun Bumbung saling balas dalam hal kebaikan dimana setiap ada kelebihan yang dimiliki oleh masyarakat mereka akan menyumbangkannya kepada masyarakat lain yang membutuhkan. Konsep tindakan besiru tidak jauh dengan gotong royong tetapi perbedaannya adalah besiru dilakukan oleh masyarakat untuk membantu pekerjaan orang lain dengan menggunakan sumberdaya atau kemampuan seadanya sehingga semua pekerjaan dikerjakan bersama-sama dengan saling mengisis kekurangan satu sama lain. Jadi Besiru ini dilakukan untuk mempermudah pekerjaan orang lain misalnya dalam suatu kegiatan seperti membuka sawah, membangun rumah, membangun hingga pekerjaan yang besar seperti membuka jalan. etiap masyarakat yang memiliki sumberdaya baik berupa apapun yang dibutuhkan dalam kegiatan itu seperti misalnya, cangkul, kerbau, alat banguna dan sebagainya maka alat itu yang dibawa untuk membantu masyarakat lain bahkan meskipun yang hanya memiliki tenaga saja maka tetap membantu sesama dengan ke mampuan seadanya yag dimlikinya. Kemudian pada situasi yag sama masyarakat yang membantu orang sebelumnya akan membantu pekerjaan yang dilakukan dengan kemampuan atau sumberdaya yang dimiliki. Hal ini yang memunculkan resiprositas atau timbal balik meskipun masyarakat tidak pernah mengharapkannya tetapi masyarakat terdorong untuk melakukannya sediri tanpa harus diminta sehingga besiru ini mejadi budaya dan dapat dikatakan sebagai suatu bentuk solidarias sosial karena membentuk prilaku kolektif serta kebersamaan secara kuat.

\section{b. Besiru dalam konstruksi sosial masyarakat}


Pada pandangan Peter L. Berger seorang sosiolog yang melihat masyarakat sebagai bentuk konstruksi sosial yang dibangun atas dasar realitas pada masyarakat dan menjadi suatu kebiasaan turun temurun yang menyatu serta masuk dalam kehidupan sosial masyarakat.

Konstruksi Sosial atas Realitas (Social Construction of Reality) didefinisikan sebagai proses sosial melalui tindakan dan interaksi yang membentuk individu atau sekelompok individu serta menciptakan secara terus-menerus suatu realitas yang dimiliki dan dialami bersama secara subjektif. Konstruksi sosial menciptakan individu menjadi manusia bebas. Individu menjadi penentu dalam dunia sosial yang dikonstruksi berdasarkan kehendaknya, dalam banyak hal memiliki kebebasan untuk bertindak di luar batas kontrol struktur dan pranata sosialnya. Dalam proses sosial, manusia dipandang sebagai pencipta realitas sosial yang relatif bebas di dalam dunia sosialnya. (Berger, 1994)

Besiru dalam konteks konstruksi sosial merupakan suatu realitas yang dibangun dan diciptakan oleh individu dengan dasar sebuah kehendak yang dipahami sebagai adaptasi dari lingkungan sekitarnya. Kemampuan individu dalam menunjukan eksisensinya akan membentuk suatu budaya yang saling terkait. Besiru sebagai budaya juga menunjukkan eksistensi manusia dalam hal gotong royong dan saling membantu satu sama lan yang didasari atas kehendak kemanusiaan dan humanisme. Hal ini merupakan suatu tindakan naluriah yang dapat menjelaskan bahwa inndividu adalah makhluk yang bebas dan dapat menentukan dunianya sendiri.

Masyarakat tidak bisa dipisahkan dengan manusia, hanya manusia saja yang hidup bermasyarakat yaitu hidup bersama-sama dengan manusia lain dan saling memandang sebagai penanggung kewajiban dan hak. Sebaliknya manusiapun tidak dapat dipisahkan dengan masyarakat. Seseorang manusia yang tidak pernah mengalami hidup bermasyarakat, tidak dapat menunaikan bakat-bakat manusianya yaitu mencapai kebudayaan, dengan kata lain di mana orang hidup bermasyarakat, pasti akan timbul kebudayaan.(Prasetia, 2011)

Pada perkembangannya besiru merupakan suatu produk dari masyarakat, Selain itu juga masyarakat dapat dipandang bentukan atas budaya yang ada seperti halnya besiru. Dialektika ini yang terbentuk dalam masyarakat sehingga Berger mencoba membuat suatu kerangka konstruksi yang dapat membuat pola perubahan dalam masyarakat. Pola perubahan yang terjadi dalam masyarakat dalam diungkapkan oleh Peter L. Berger akan melalui 3 tahap yang terus menerus berputar dan saling terkait. Proses dialektik fundamental dari masyarakat terdiri dari tiga momentum, atau langkah yaitu ekternalisasi, objektivasi, dan internalisasi. Pemahaman secara seksama terhadap tiga momentum ini akan diperoleh suatu pandangan atas masyarakat yang memadai secara empiris. (Berger, 1994)

\section{a. Ekternalisasi}

Eksternalisasi adalah proses pencurahan kedirian manusia secara terus menerus kedalam dunia, baik dalam aktifitas fisik maupun mentalnya. Sudah merupakan suatu keharusan antropologis, manusia selalu mencurahkan diri ketempat dimana ia berada. Manusia tidak dapat dimengerti sebagai ketertutupan yang lepas dari dunia luarnya. Proses eksternalisasi dalam penelitian adalah awal mula konstruksi sosial dapat dipahami. Konstruksi sosial dibangun berdasarkan wacana, realitas, maupun kebijakan yang berlaku di masyarakat. (Muta'afi dan Handoyo, 2015) 
Besiru dalam konstruksi sosial merupakan produk masyarakat yang terbentuk atas interaksi sosial dan pola tingkah laku masyarakat. Produk masyarakat ini diawali dengan pencurahan diri ke dunia sehingga memunculkan suatu tindakan yang bisa diamati secara empiris. Pencurahan diri secara sederhada diartikan seagai suatu tindakan mengeluarkan isi dari ide maupun gagasan yang dimiliki ke dunia empiris sehingga dapat diamati dan dipahami oleh masyarakat

Eksternalisasi juga dianggap sebagai momen adaptasi diri dengan sosio-kultural. Dalam momen ini, sarana yang digunakan adalah bahasa dan tindakan. Manusia menggunakan bahasa untuk melakukan adaptasi dengan dunia sosio-kulturalnya dan kemudian tindakannya juga disesuaikan dengan dunia sosio-kulturalnya. Pada momen ini, terkadang dijumpai orang yang mampu beradaptasi dan juga ada juga yang tidak mampu beradaptasi. Penerimaan dan penolakan tergantung dari mampu atau tidaknya individu untuk menyesuaikan dengan dunia sosio-kultural tersebut.(Syam, 2015)

Masyarakat adalah produk dari manusia, berakar dalam fenomena eksternalisasi, yang pada gilirannya didasarkan pada kondisi kontruksi manusia. Tranformasi produkproduk manusia ini ke dalam suatu dunia tidak saja berasal dari manusia, tetapi yang kemudian menghadapi manusia sebagai suatu faksifitas di luar dirinya, adalah diletakkan dalam konsep objektivasi, dunia yang diproduksi manusia ini kemudian menjadi sesuatu yang berbeda diluar sana. Dunia ini terdiri dari benda-benda, baik material maupun nonmaterial, yang mampu menentang kehendak produsennya. Kebudayaan itu berada di dalam subyektivitas individual sebagaimana juga dunia. Dengan kata lain dunia yang diproduksi manusia memperoleh sifat realitas objek. (Fawais, 2016)

Proses eksternalisasi pada budaya Besiru menunjukan suatu bentuk pencurahan diri masyarakat terhadap dunia sosial yang terdapat dalam pengalaman, pengetahuan serta pemahaman masyarakat. Pencurahan diri ini membentuk suatu indakan dalam masyarakat diaman yang disebut dengan besiru atau saling tolong-menolong itu adalah ketika masyarakat. Hal ini disebab sekitar sebabkan karena pada zaman dahulu Sembalun didiami oleh beberapa orang sekitar 300 hingga 700 orang sebagaimana yag disebutkan oleh ketua adat

"Pada zaman dahulu pada saat sembalun didiami oleh 300 penduduk hingga 700 penduduk sembalun merupakan daerah yang aman dari bencana karena masyarakatnya tetap menjaga hubungannya dengan alam"

Kondisi tersebutlah yang membuat masyarakat bersama-sama karena harus menjaga hubugan dengan alam, menjaga hubungan dengan manusia agar bisa saling membantu satu sama lain jika dibutuhkan. Sedikitnya masyarakat sembalun pada jaman dahulu inilah yang memunculkan Solidaritas berupa besiru. Oleh karena itu konsep Besiru ini muncul untuk mengatasi kekurangan masyarakat seperti halnya kekurangan sumberdaya atau alat yang dimiliki untuk menyelesaikan pekerjaannya maka dibantu oleh orang lain yang memiliki sumberdaya atau alat yang dibutuhkan.

Pada zaman Besiur dilakukan pada konteks pertanian dan secara bersama-sama mulai dari dari mengolah tanah pertanian, menanam hingga melaksanakan panen secara bergilir tanpa upah. Sebagaimana informasi dari salah satu informan

Aktivitas awal pertanian yang dilakukan pada zaman dahulu oleh masyarakat di Desa Sembalun Sembalun adalah hanya sebatas menanam padi. Masyarakat di Desa 
Sembalun Bumbung mengartikan besiru juga sebagai perilaku sosial masyarakat terkait dengan solidaritas sosial antar sesama sebagaimana ungkapan dari salah satu informan.

“ min masyarakat sembalun besiru kami lakuang pertama kami mulai lelek nanem pade. Kami min desa sembalun nene bareng-bareng ngolah tanak ngadu cangkul, sapi kanca kebo. Bagi masyarakat ita bedeang cangkul ngantik cangkul, lamun arak bedeang sampi ato kebo ngantik kebo ato bdeang tenaga doang antik wah tenaga yang penting ta bareng-bareng nulung baturta ngolah tanak ta kadu nanem pade sampai namanen iya padeno tetep ita saling bantu.

Artinya Aktivitas besiruan tersebut dimulai dari melakukan pengolahan tanah secara bersama-sama masyarakat yang memiliki sapi atau kerbau akan membawa sapi atau kerbaunya sebagai alat bajak sawah dan bagi masyarakat yang tidak memiliki sapi atau kerbau akan membantu melalu tenaga dan membawa cangkul. Setelah proses tersebut, maka dilanjutkan dengan Aktivitas Lowong padi secara bersama-sama hingga menempatkan hasil panen ke lumbung.

Hal ini juga diperkuat dengan informasi dari tokoh adat. "Tindakan besiruan pada era tradisional berawal dari aktivitas pertanian yakni proses penanaman padi karena pada zaman dahulu varitas pertanian yang ditanam oleh masyarakat sembalun hanyalah padi. Aktivitas besiruan tersebut dimulai dari melakukan pengolahan tanah secara bersamasama dan bagi masyarakat yang memiliki sapi atau kerbau akan membawa sapi atau kerbaunya sebagai alat bajak sawah dan bagi masyarakat yang tidak memiliki sapi atau kerbau akan membantu melalu tenaga dan membawa cangkul. Setelah proses tersebut, maka dilanjutkan dengan Aktivitas Lowong padi secara bersama-sama hingga menempatkan hasil panen ke lumbung"

Bentuk tindakan yang dilakukan oleh masyarakat inilah yang diseburt sebagai besiru dimana pekerjaan dilakukan sampai selesai secara bersama-sama. Sehingga dalam masyarakat zaman dahulu terbentuk kelompok-kelompok atau disebut sebagai bebudutan. Sedangkan besiru adalah perilaku tolong menolong yang saling membalas, seperti kelompok pemilik ternak misalnya kerbau maka membantu kelompok petani dalam membajak sawah dan nantinya kelompok petani akan membantu pemilik kerbau dalam hal lain, maka disini muncul resiprositas yang saling membantu terhadap kelebihan yang dimiliki masing-masing, kemudian suatu saat masyarakat kelompok petani bisa membantu kelompok yang membuat ternah sehingga pada zaman dahulu masyarakat Sembalun tidak terlalu membutuhkan uang, melainkan hanya membutuhkan bahan-bahan yang tidak ada di Sembalun seperti gula, kelapa, minyak.

Selanjutnya eksternalisasi dari besiru di Desa Sembalun Bumbung terus berkembang dengan terlihat pada kegiatan pembukaan jalan di Sembalun hingga Pesugulan. Besiruan dalam pembukaan jalan tersebut tidak hanya dilakukan oleh masyarakat Sembalun saja, melainkan melibatkan partisipasi masyarakat dari kecamatankecamatan lain yang secara geografis dekat dengan daerah Sembalun seperti kecamatan Pringgabaya, Wanasaba, Aikmel dan Suela.

Tidak hanya itu, dari segi budaya tindakan besiru dapat dilihat dari kegiatan saling membantu antar masyarakat pada saat adanya kegiatan Begawe baik untuk acara khitanan, kematian, pernikahan maupun haji. Pada saat acara tersebut, masyarakat di Desa Sembalun melakukan besiru dengan mengeluarkan kelapa sama-sama dua buah dan membawa kayu satu ikat per orang khusus bagi laki-laki dan membawa beras, telur 
dan gula bagi yang perempuan. Selain itu, masayarakat juga melakukan pembagian kerja dengan adanya tugas masing-masing, seperti ada yang bertugas menjadi panitia penangung jawab untuk memasak nasi dan ada yang bertanggung jawab untuk memasak lauk-pauk serta bertugas untuk menyiapkan bahan-bahan dan alat-alat yang akan digunakan untuk memasak. hal ini sebagaimana ungkapan informan :

"lamun na arak batur ita begawe min Sembalun Bumbung ne lapuan batur min sembalun saling tulung lamun dengan mama nyugulang kayu minimal arak dua kanca nyur, lamun dengan nina nyugulang beras, telur kanca minyak karena ita jaok lelek kota jari ita ngadu sistem marak arisan"

Artinya pada saat acara Begawe baik itu untuk acara kematian, pernikahan maupun sunatan maka berdasrkan kebiasaan atau budaya yang ada masyarakat khususnya lakilaki sama-sama mengeluarkan kayu dan kelapa dua buah serta bagi perempuan khusus mengeluarkan beras, minyak dan telur sebagai solusi untuk mempermudah pemenuhan bahan-bahan karena masyarakat di Desa Sembalun Bumbung sangat daerahnya jauh dari pusat kota.

\section{b. Obyektivasi}

Objektivasi, yaitu interaksi sosial yang terjadi dalam dunia subjektif yang dilembagakan atau mengalami proses institusional. Realitas sosial seakan-akan berada di luar diri manusia. la menjadi realitas objektif. Karena objektif, sepertinya ada dua realitas, yaitu realita diri yang subjektif dan realita lainnya yang berada di luar diri yang objektif. Dua realitas itu membentuk jaringan interaksi intersubjektif melalui proses pelembagaan institusional. Pelembagaan atau institusional, yaitu proses untuk membangun kesadaran menjadi tindakan. Tidak dibutuhkan lagi berbagai penafsiran terhadap tindakan, karena tindakan tersebut telah menjadi bagian dari system kognitif dan system evaluatifnya. Peta kesadarannya telah menerima dan system evaluasi yang berasal dari system nilai juga telah menjadi bagian di dalam seluruh mekanisme kehidupannya. Dengan demikian, ketika suatu tindakan telah menjadi suatu yang habitual, maka telah menjadi tindakan yang mekanis, yang mesti dilakukan begitu saja. (Syam, 2015)

Kontruksi sosial manusia yang dapat secara akurat disebut sebagai fenomena sosial jika kontruksi tersebut sudah mencapai tingkat obyektivitas yang memaksa individu mengakui sebagai nyata. Dengan kata lain, sifat pemaksa utama dari masyarakat itu tidak terletak peralatan-peralatan kontrol sosialnya, tetapi pada kekuasaanya untuk membentuk dan menerapkan dirinya sebagai realitas. (Fawais, 2016)

Pada tahap objektivasi kebudayaan yang diciptakan manusia kemudian menghadapi penciptanya sebagai suatu yang berada diluarnya atau menjadi suatu realitas objektif. Dalam hal ini manusia atau masyarakat yang menciptakan suatu wacana, akan mengalami dan merasakan apa yang ia wacanakan sendiri. Melalui tahapan ini masyarakat menjadi suatu realitas objektif. Objektivasi merupakan hasil yang telah dicapai, baik mental maupun fisik dari kegiatan eksternalisasi manusia. Kenyataan hidup sehari-hari itu diobjektivasi oleh manusia atau dipahami sebagai realitas objektif. Objektivasi dalam masyarakat meliputi beberapa unsur misalnya institusi, peranan dan identitas. (Muta'afi dan Handoyo, 2015)

Proses Obyektivasi pada Besiru merupakan suatu realitas Obyektif yang terbentuk atas kearifan lokal yang dimiliki oleh masyarakat Sembalun. Masyarakat Sembalun kini 
secara luas menganut tindakan Besiru sebagai bentuk saling tolong menolong dan gotong royong dalam berbagai segi kehidupan sosial baik dari tindakan kematian, kelahiran, pernikahan, maupun haji. Beberapa hal yang membentuk Besiru sebagai suatu realitas Obyektif, dimana besiru menjadi suatu pemahaman bersama dan diketahui oleh masyarakat antar alain, Tindakan Besiru sebagai kearifan lokal yang memiliki nilai-nilai dan dianut oleh masyarakat sebagai nilai-nilai yang dipegang dalam menjalani hidup. Selain itu erdapat suatu landasan yang diketahui bersama dalam menjaga hubungan baik dengan alam semesta baik secara vertikal maupun horizontal. Selanjutnya dalam besiru memiliki sifat memaksa yang artinya ada suatu kondisi yang membentuk masyarakat seperti norma dan sanksi yang diberikan ketika tidak ikut partisipasi dalam pelaksanaan besiru. Dalam Obyektivasi realitas berusaha ditarik pada pandangan masyarakat secara umum, makro dan universal. Beberapa pandangan masyarakat secara realias obyektif antara lain:

\section{a. 3 Pedoman Hidup Masyarakat Sembalun}

Pedoman hidup merupakan jalan atau landasan yang digunakan oleh masyarakat dalam hidup dengan lingkungannya baik lingkunan fisik, non fisik maupun sosialnya. Pada masyarakat Sembalun secara realitas obyektif bahwa dipahami secara bersama sebagai cara masyarakat untuk hidup memiliki 3 landasan hidup. 3 Landasan hidup ini dahulunya didasari oleh pemahaman masyarakat bahwa pada zaman dahulu Sembalun merupakan tempat para waliyulllah atau para auliya untuk melihat kebesaran Allah dan berdzikir untuk mendekatkan diri kepada Allah. Masyarakat yang mendiami Sembalun memiliki perjanjian dengan penguasa pulau dan para Auliya Allah agar sembalun ini dipelihara karena pada hakekatnya sembahulun ini adalah tempat berkhalwat (mengasingkan diri untuk berdzikir) mengingat Allah. Sebagaimana yang dijelaskan oleh ketua adat bahwa.

"Para waliyulllah atau para auliya datang ke sembalun untuk melihat kebesaran Allah dan berdzikir untuk mendekatkan diri kepada Allah"

Oleh karena pemahaman masyarakat seperti itu maka secara obyektf masyarakat juga membentuk suatu landasan hidup yang terdri dari 3 landasan

"Masyarakat sembalun adalah masyarakat yang senantiasa berpegang teguh pada al-qur'an. Pada masayarakat sembalun ada 3 hal yang menjadi landasan dalam hidupnya yakni Hablummina ALLAH (Menjaga hubungan dengan Allah), hablummina An-Nas (menjaga hubungan kerukunan dengan semua manusia yang diimplementasikan dengan bersikap baik dan ramah kepada semua orang baik itu saudara yang kita kenal atau yang tidak kita kenal bahkan orang-orang yang berasal dari agama yang berbeda akan senatiasa akan kita hargai selama mereka tidak menggangu interaksi dan keberlangsungan kehidupan antar masyarakat sembalun. Selanjutnya Hablum Minal Alam menjaga hubungan dengan Alam. Artinya setiap tindakan dan perilaku yang dilakukan harus arif terhadap alam dan tidak boleh berdasarkan kehendak semata tanpa memperdulikan alam" Dijelaskan oleh ketua adat 
Sehingga 3 landasan hidup yang dipahami tersebutlah besiur memiliki nilainilai yang saat in terus dipahami bersama oleh masyarakat :

$>$ Hablummina Allah (Menjaga hubungan dengan Allah) yang tercermin dari masyarakatnya yang religius, selalu berusaha untuk tetap mendirikan sholat dan menjaga tauhidnya agar jangan sampai goyah. Hubungan dengan Allah juga mencerminkan tentang ajaran-ajaran agama seperti saling memberi bahkan dianjurkan untuk tolong-menolong dalam kebaikan seperti dalam surah Al-Maidah ayat 2 "Dan tolong-menolonglah kamu dalam (mengerjakan) kebajikan dan takwa, dan jangan tolongmenolong dalam berbuat dosa dan pelanggaran. Dan bertakwalah kamu kepada Allah, sesungguhnya Allah amat berat siksa-Nya”. Dengan mencerminka prilaku sesuai dengan perintah dan larangan agama maka masyarakat mencoba terus patuh kepada ajaran agamanya khususnya ajaran agama Islam. Selain itu juga dengan menjaga hubungan dengan Allah, masyarakat mengerti arti keikhlasan bahwa apa yang mereka lakukan jika tidak adan timbal baliknya juga tidak maslah, yang penting mereka telah mencoba membantu sesama yang membutuhkan.

$>$ Hablummina An-Nas (menjaga hubungan kerukunan dengan semua manusia) yang diimplementasikan dengan bersikap baik dan ramah kepada semua orang baik itu saudara yang dikenal atau yang tidak dikenal bahkan orang-orang yang berasal dari agama yang berbeda akan senatiasa dihargai selama mereka tidak menggangu interaksi dan keberlangsungan kehidupan antar masyarakat Sembalun. Menjaga hubungan dengan manusia merupakan hal yang paling dipahami oleh masyarakat luas ketika melakukan tindakan besiru karena seling menguatkan solidaritas juga dapat menjalin silaturrahmi satu sama lain sehingga kolektifitas dan kebersamaan tidak terputus.

Hablum Minal Alam menjaga hubungan dengan Alam artinya setiap tindakan dan perilaku yang dilakukan harus arif terhadap alam dan tidak boleh berdasarkan kehendak semata tanpa memperdulikan alam karena pada zaman dahulu Sembalun hanyalah berbentuk seperti hutan belantara yang dikeliling oleh pohon-pohon sehingga mereka sangat menjaga hubungan baik dengan alam bahkan masyarakat Sembalun juga memiliki kemampuan untuk berbicara dengan batu, kayu, gunung. Hal ini dikarenakan setiap masyarakat ingin memanfaatkan pohon-pohon atau hal lain dari alam masyarakat Sembalun selalu meminta izin kepada batu, gunung dan kayu tersebut dikarenkan masyarakat beranggapan bahwa benda-benda tersebut memiliki aturan. Selain itu menjaga hubungan engan alam mencerinkan tindakan besiru dimana dalam pelksanaannya besiru selalu terkait dengan alam baik dalam pelaksanaan pertanian, atau dalam pekerjaan yag lain. Alam memiliki potensi besar untuk menyambung tindkan besiru seperti memberikan sumberdaya alam yang lebih kepada tetangga yang membutuhkan saat begawe misalnya atau menyumbang kerbau saat ada orang yang ingin membajak sawahnya sehingga disumbangkan agar digunakan membantu pekerjaan petani 
sehingga keberadaan alam dalam tindakan besiru perlu dijaga dengan baik. Oleh karen itu mejaga hubungan dengan alam sangat penting bagi masyarakat Sembalun.

\section{b. Besiru merupakan nilai kearifan lokal}

Besiru sebagai kearifan lokal masyarakat memiliki nilai-nilai yang dianut bersama oleh masyarakat. Nlai-nilai ini yang melekat pada besiru sehingga pada realitas obyektif nilai-nilai besiru ini dapat dipahami oleh masyarakat secara luas. Adapun beberapa nilai tersebut antara lain

\section{- $\quad$ Nilai toleransi}

Toleransi merupakan sikap saling menghormati dan saling menghargai antara sesama. Secara realitas obyektif toleransi tercermin dalam Besiru karena masyarakat yang dibantu dalam kegiatan besiruan ini tidak memandang siapa saja meskipun mereka seorang pedatang baru, ataupun masyarakat yag telah lama menetap, baik dari suku sasak maupun dari suku lain bahkan ada juga yang berasal dari australia yang menetap di Sembalun namun masyarakat akan tetap membantu jika ada pekerjaan yang dilakukan sebisa mungkin. Selain itu perbedaan agama juga tidak menutup prilaku masyarakat untuk melakukan tindakan Besiru. Hal ini juga dipejelas dari informan (amaq Ema) bahwa "Masyarakat Sembalun sering menolong orang-orang terutama orang-orang yang tersesat atau tidak tahu jalan. Selain itu juga masyarakat sembalun sering membantu dengan memberikan makanan atau kopi kepada orang yang tersesat atau orang lain yang datang ke desa Sembalun. Bahkan turis pun akan tetap ditolong tanpa memandang agama, suku,dan lain sebagainya". Nilai toleransi ini yang muncul menjadi sebuah nilai yang sangat penting ketika melihat praktik Besiru dilakukan.

\section{- Nilai kebersamaan dan persatuan}

Pada saat melakukan tindakan Besiru ini nilai kebersamaan akan muncul serta akan terbentuk persatuan. Hal ini dibuktikan dengan sedikitnya angka kriminalitas dan konflik yang terjadi bahkan hampir tidak ada. Kebersamaan masyarakat yang kuat juga terlihat dalam kegiata besiru, dimana masyarakat ketika ada pekerjaan maka setiap warga akan datang membantu untuk menyelesaikannya dan masyarakat akan membawa alat maupun sumberdaya yang dibutuhkan dalam pekerjaan terebut sehingga inilah yang membentuk nilai-nilai kebersamaan yang terihat dalam Besiru. Hal ini juga diperkuat dengan ucapan tokoh adat bahwa "kita membentuk kelompok untuk membantu Si A, Maka setelah selesai kelompok tersebut si $A$ akan bergabung dengan kelompok tersebut untuk membantu masyarakat yang lain hingga semua pekerjaan yang akan dikerjakan selesai dan semua urusan masyarakat selesai”. Kelompok-kelompok tersebutlah yang nantinya membuat kebersamaan dan persatuan semakin kuat sehingga dalam besiru muncul nilai kebersamaan dan persatuan.

\section{- $\quad$ Nilai Tolong menolong}


Nilai yang paling jelas terlihat dalam peraktek Besiru adalah nilai tolong menolong karena nilai ini yang menjadi landasan masyarakat untuk melakukan tindakan besiru. Besiru pada dasaanya merupakan suatu implementasi dari nilai tolong menolong agar memudahkan pekerjaan masyarakat. Pada dasarnya tolong menolong dalam besiru ini merupakan sebuah nilai dasar yang membentuk masyarakat. Secara pandangan empiri Besiru atau dalam bahasa sasak disebut sebagai saling balas seperti layaknya dialektika yang tidak terputus. Ketika menolong orang yang kesusahan dalam pekerjaannbya, masyarakat selalu memahami kondisi seakan-akan mereka juga memiliki masalah yang sama atau rasa empati masyarakat tinggi sehingga masyaraat terus membantu satu sama lain sehingga pekerjaan mereka selesai terutama pada acara begawe, acara kematian, acara kelahiran, atau acara pernikaha, dimana membutuhkan banyak dana dan tenaga. Masyarakat mencoba memposisikan diri sebagai orang tersebut dan pasti akan kewalahan jika tidak ditolong. Oleh karena itu masyrakat dengan tindakan besiru ini mencba menolong satu sama lain begitu juga masyarakat yang lain akan membatu sehingga ini menjadi suatu realitas yang dpahami masyarakat secara bersama bahwa menolong sesama akan mempermudah pekejaan.

Niali yang terkandung dalam besiru merupakan suatu nilai yang terkandung yang membentuk besiru sebagai earifn lokal dalam masyarakat. Nilai tersebut bersifat obyektif karena dipahami bersama oleh masyarakat secara empiris bukan pemaknaan masyarakat melainkan suatu nilai yang tampak dan dapat diamati. Oleh karena itu kearifa lokal besiru dapat menjadi relaitas obyektif dalam obyektivasi.

\section{c. Aturan dalam Besiru}

Besiru bersifat memkasa dan berasal dari luar individu atau telah menjadi fakta sosial dalam masayarakat yang bersifat universal dan tentunya membentuk tindakan masyarakat. Hal yang dimaksud adalah Besiru pada realitas obyektif ini merupakan sebuah nilai-nilai masayarakat yang bersifat memaksa dan dianggap penting oleh masyarakat. Meskipun pada prakteknya Besiru tidak memiliki aturan tertulis maupun secara institusional tidak ada tetapi secara sosial, nilai dan kultur masyarakat tentu bersifat memkasa secara tidak langsug. Kolektifitas dan solidaritas merupakan salah satu energi yang bersifat memkasa individu untuk ikut dalam sebuah lingkungan kolektif yang terintegrasi dalam masyarakat.

Bagi masyarakat yang tidak mengikuti besiru tidak terdapat hukuman secara tertulis maupun tidak tertulis seperti awiq-awiq desa yang secara jelas mengaturnya melainkan diberikan sanksi sosial. Dalam beberapa pandangan besiru memiliki sanksi sosial seperti dikatakan oleh ketua pemuda (Junaedi S.H.)

"Lamunna arak masyarakat min desa sembalun nene yakda milu besiru misalna untuk kegiatan irigasi sawah, jarina ida pada yakda milu no yakda ngimbeng aik untuk tanaman ida pada “ 
Artinya ketika ada salah seorang warga yang tidak berpartisipasi dalam kegiatan besiru seperti irigasi sawah secara bersama-sama, maka bagi mereka yang tidak ikut tidak akan diberikan air untuk irigasi sawahnya.

Hukuman yang diberikan tidak hanya berupa sanksi sosial melainkan masyarakat yang tidak mengikuti besiru mereka akan merasa malu karena hanya jika mereka ada kegiatan mereka membutuhkan orang lain. oleh karena itu, masyarakat di Desa Sembalun Bumbung menganngap bahwa cara ini efektif untuk menjaga besiru dalam kehidupan masyarakat.

Solidaritas dan kolektifitas yang kuat nantinya akan membentuk sebuah pola integrasi yang kuat pula, dimana masyarakat yang ada didalamnya akan dipaksa untuk ikut dalam pola masyarakat. Visibilitas masyarakat secara keseluruhan terhadap penilaian tindakan membentuk sebuah nilai-nilai yang dianut berama dan ketika ada yang tidak mengikutinya atau tidak terintegrasi dengan masyarakat maka masyarakat akan mengasingkannya dan itu membuat sebuah alienasi dalam lingkungan sosial yang memaksa individu harus mengakui realitas obyejtif yang terjadi dalam masyarakat.

\section{c. Internalisasi}

Internalisasi adalah proses individu melakukan identifikasi dari di dalam dunia sosiokulturalnya. Internalisasi merupakan momen penarikan realitas sosial ke dalam diri atau realitas sosial menjadi kenyataan subjektif. Realitas sosial itu berada di dalam diri manusia dan dengan cara itu maka diri manusia akan teridentifikasi di dalam dunia sosiokulturalnya. Secara kodrati, manusia memiliki kecenderungan untuk mengelompokkan. Artinya, manusia akan selalu berada di dalam kelompok, yang kebanyakan didasarkan atas rasa seidentitas. Sekat interaksi tidak dijumpai jika manusia berada di dalam identitas yang sama. (Syam 2015).

Proses internalisasi merupakan penyerapan kembali dunia objektif kedalam kesadaran sedemikian rupa sehingga subjektif individu dipengaruhi oleh struksur dunia sosial. Internalisasi merupakan momen penarikan realitas sosial kedalam diri atau realitas sosial menjadi realitas subjektif. Realitas sosial itu berada didalam diri manusia dan dengan cara itu maka diri manusia akan teridentifikasi didalam dunia sosio kultural. (Berger dan Luckmann, 1990;23-24)

Setiap masyarakat selalu menghadapi persoalan bagaimana meneruskan peranan sosial yang dibangun kepada generasi berikutnya. Proses ini disebut sosialisasi. Dalam proses sosialisasi itu makna dari pranata sosial harus dijelaskan sedemikian rupa, sehingga dapat diterima oleh individu (subjectively plausible). Fungsi legitimasi adalah kognitif, yang menjelaskan mengenai makna realitas sosial dan normative, yaitu memberikan pedoman bagaimana seseorang harus berlaku. Tujuan dari segala bentuk legitimasi adalah mempertahankan realitas. Ada berbagai tingkat legitimasi, dari kosa kata yang paling sederhana meningkat kepada kata-kata mutiara, legenda, perumpamaan, perintah-perintah moral sampai kepada yang paling canggih yaitu berbagai sistem simbol termasuk teori ilmiah. (Berger, 1994)

Proses internalisasi dipandang sebagai suatu bentuk penyerapan niali-nilai yang terdapat dalam obyektivasi menjadi suatu realitas subyektif. Proses penyerapan nilai-nilai ini tentu melalui sosialisasi yang dilakukan oleh masyarakat baik sosialisasi secara 
lagsung maupun tidak langsung. Sosialisasi merupakan bentuk dari penyebran dan embentuk sosio-kulture dalam diri masyarakat sehingga setiap masyarakat dapat memaknai tindaka besiru. Dalam sosialisasi terdapat agen sosialisasi yang menjadi bentuk transfer of knwoledge yang dapat membantu dlam penanaman nilai-nilai Besiru

\section{- Keluarga}

Keluarga merupakan kelompok terkecil dalam masyarakat. Keluarga dapat membentuk anak prilaku, sifat dan pola ineraksi anak karena keluarga merupakan kehidupan sosial pertama anak. Dalam besiru anak diajarkan nilai-nilai menghargai dan menghormati tamu, seperti halnya berdasarkan pengamatan yang dilakukan bahwa ketika ada orang bertamu anak-anak dididik untuk tidak mengganggu tamu dan diajarka untuk menhargai tamu. Dalam penelitian, peneliti menginap disalah satu rumah warga dan warga tersebut mencoba memberikan suatu nasehat kepada anak agar membiarkan tamu untuk menginap dikamarnya. Proses ini menunjukkan bahwa adanya penanaman nilai memberikan orang yang membutuhkan seperti dalam nilai-nilai yang ada pada besiru.

Hal ini juga iperkuat dengan pernyataan ketua remaja (Junaedi S.H.) bahwa "Besiru juga diperkenalakan dengan cara para orang tua menceritakan kepada anak-anaknya bahwa pada masyarakat di Desa Sembalun ini ketika membangun rumah mereka tidak menggunakan uang tetapi masyarakat berkumpul untuk saling membantu sama lain. Oleh karena itu, hal tersebut orang tua mengajarkan nilai persaudaraan dan persatuan yang ada di Desa Sembalun, jadi diwariskan kepada generasi muda dimulai sejak anak-anak dan akhirnya terbentuklah sebuah persatuan, seperti ketika orang begawe maka dipergunakanlah persatuan tersebut dimana persatuan ini yang akan mengkordinir acara pesta tersebut dari awal hingga akhir".

\section{- Lingkungan sosial}

Lingkungan sosial merupakan agen sosialisasi yang dapat membentuk masyarakat ikut dalam kegiatan besiru dan mendalami nilai-nilai yang terkandung dalam besiru. Melalui lingkungan sosial masyarakat pendatang akan dibantu mencari jalan, ataupun yang menetap akan dibatu dalam membangun rumah jika diperlukan. Prilaku masyarakat yag ramah dan membantu orang lain juga akan tidak sugkan untuk berinteraksi sehingga penndatangpun iku dalam kegiatan besiru jika diajak karena telah dibantu sebelumnya. Kondisi ini yang membentuk suatu kolektiftas serta integrasi yang kuat dalam masyarakat.

Pada anak ingkungan sosial juga penting dimanna ketika ada acara begawe anak dilibatkan sehingga para orang tua yang membantu berlangsungnya acara begawe tersebut sedangkan anak-anak dibiarkan bermain dengan anak-anak lain. Dari interaksi tersebut para anak-anak belajar arti persaudaraan dan dalam acara tersebut anak-anak juga diberikan makan dengan sistem begibung atau mangan bantar (makan secara berkumpul). Melalui begibung tersebut juga secara tidak langsung salah satu cara diperkenalkan dan diajarkan besiru kepada anak-anak.

\section{- Pendidikan}

Pendidian sebagai agen sosialisasi bisa berupa pendidikann formal ataupun nonformal. Salah satu pendidkan nonformal seperti sosialisasi yang dilakukan oleh 
tokoh adat dalam menanamkan nilai-nilai besiru melalui program-program yang dijalankan.

" cara kami jari selaku tokoh adat ngenalang besiru dengan sering ngadaang sosialisasi tentang pentingna jaga kearifan lokal bedeang itaendah wah luik anak-anak ita sekolah bependidikan jarina mudak ita sosialisasiang antekna terus jaga budaya besiru nene.

Artinya cara untuk melestarikan tindakan besiruan ini adalah salah satunya dengan sering mengadakan sosialisasi kepada pemuda terkait pentingnya menjaga kearifan lokal yang telah dimiliki dan diwariskan oleh generasi sebelumnya agar semua kearifan lokal tersebut terus dijaga dan diimplementasikan serta jangan sampai hilang. Dengan kondisi para pemuda Sembalun Bumbung yang saat ini sudah banyak yang berpendidikan upaya untuk menyampaikan sosialisasi tersebut tidak memiliki hambatan bahkan mereka cepat memahami.

Pendidikan nonformal melalui sosialisasi merupakan pendidika yang baik terutama bagi masyarakat agar tercapai internalisasi yang baik dalam masyarakat. Selain itu dalam pendidikan formal juga terdpat penanaman nilai-nilai dalam masyarakat tentang besiru. Agen pendidikan formal inilah yang membentuk perbedaan pemikiran sehinggan masyarakat yang memiliki pendidikan tinggi dan sekolah atau menuntut ilmu pada diluar daerahnya maka pemikirannya juga lebih luas tentang besiru yang didapatkan sehingga inilah yang dapat membedakan cara pandang masyarakat terkait internalisasi dalam Besiru.

Selanjutnya, Internalisasi masyarakat tehadap tindakan Besiru merupakan sebuah pemaknaan subyetif atas realitas obyektif yang dipandang sebagai kearifan lokal masyarkat. Individu mencoba menarik diri dari realitas obyektif untuk memenuhi pemaknaan tersendiri terhadap tindakan Besiru. Berdasarkan perbedaan pemaknaan yang ada di masyarakat terbagi menjadi pemaknaan pemuda, pemaknaan Orang tua, dan pemaknaan ketua adat.

\section{a. Pemaknaan golongan Orang tua (bapak-bapak dan Ibu-ibu)}

Seorang informan bernama Inaq Salju memaknai Besiru sebagai bentuk kebaikan dan keramahannya kepada semua orang baik terhadap saudara, sesama orang Lombok maupun kepada para pengunjung domestik dan internasional. Hal ini tercermin dari kebiasaan masyarakat di Desa Sembalun Bumbung yang sering menolong orang lain yang belum pernah mereka kenal secara baik.

"Masyarakat min Desa Sembalun Bumbung nene lamunna arak dengan kesasar pasti ginta tolong marak piranna arak dengan jual topi petani no laguk sampe mal ndarak laku terus da keto kete doang sang ndark langanda tindok yakna sengaja amakda nak salju liwat tenakda ka iya kite timpak bale alasanda awaku na bli topi pe kanca ito wah pe tindok min bale ahkelem jemak pe lanjutang dagangan pe"

Artinya masyarakat di Desa Sembalun Bumbung jika melihat ada orang yang tersesat atau pulang larut malam dan mereka tidak memiliki saudara atau tempat untuk menginap, maka masyarakat akan menawarkan mereka untuk menginap di rumahnya, seperti kemaren suami saya melihat ada seorang bapak penjual topi 
sawah yang masih di Sembalun Bumbung sampai malam dan ia tidak memiliki tempat untuk menginap kemudian suami saya mengajaknya ke rumah dan kami membeli topi yang dijual meskipun kami tidak bekerja di sawah karena kami membayangkan bagaimana jika kami diposisi bapak tersebut.

Besiru atau sikap tolong menolong membentuk rasa empati ibu-ibu terhadap masyarakat lain sehingga muncul rasa ingin menolong sebisa mungkin dan membantu orang lain meskipun tidak dikenal.

Pentingnya besiru bagi masyarakat Sembalun diungkapkan oleh Amaq Ema.

"Besiru ne penting untuk ngajar ita jaga rasa kekeluargaan kanca saling merasa saudara "

karena Besiru dapat menjaga rasa kekeluargaan dan saling memiliki di antara anggota masyarakatnya. Sedangkan bagi ibu-ibu Tradisi Besiruan ini dapat menghemat pengeluaran.

" Tradisi besiruan ngimbeng ita berhemat pengeluaran ita soalna kerjaan ita bareng-bareng lapukna kanca yak ita ulak nyugulang kepeng hanya kadu mangan doang " ungkap inaq Salju

Dalam mengerjakan sesuatu seperti membuat pondasi rumah atau menanam bawang putih masyarakat tidak perlu dibayar hanya disediakan makanan saja.

\section{b. Pemaknaan Tokoh adat}

Tindakan besiruan ini merupakan implementasi dari sikap saling sayang menyayang baik antar sesama saudara, sesama agama bahkan tindakan besiruan ini juga mengajarkan kita untuk peduli dan menyayangi serta menghormati orang yang berbeda agama dengan kita untuk tetap menjalin hubungan baik dan memiliki jiwa toleransi. Selanjutnya dengan masyarakat tetap menjaga dan mengimplementasikan tindakan besiruan ini sangat jarang terjadi kasus kekerasan

Kecamatan Sembalun adalah salah satu kecamatan yang aman karena kejahatan didaerah ini sangat jarang sehingga rumah masyarakat jarang dikunci dan masyarakat sembalun tidak ada yang berurusan dengan polisi. Hal ini disebabkan karena jika ada seseorang yang ingin mencuri maka akses untuk jalan keluar sangat susah karena daerah sembalun yang luas dan dikelilingi hutan serta di pintu jalan keluar daerah Sembalun terdapat sektor-sektor kepolisisan seperti di daerah Suela, Pringgasela, Aikmel, Wanasaba ataupun jika ingin melalui daerah lain yakni Pringgabaya dan Labuan Lombok namun daerah tersebut juga terdapat sektor kepolisian.

\section{c. Pemaknaan Pemuda}

Bagi para pemua Besiru dianggap sebagai sesuatu yang sangat penting dalam kehidupan dan menjadi salah satu kekayaan yang dimiliki oleh Desa Sembalun Bumbung, dimana tanpa besiru tersebut tidak akan dapat tercipta sebuah program yang bertujuan untuk saling membantu satu sama lain.

"Besiru sangat penting bagi kami para pemuda khususnya sebagai generasi lanjutan kanca salah satu kekayaan bedeang kami min Sembalun Bumbung nene soalna tanpa besiru program piak ita yak na gin jalan untuk bantu masyarakat " (Junaedi S.H.)

Pemuda di Desa Sembalun Bumbung khususnya pemuda di Dusun Jorong juga dalam memaknai Besiru atau sikap tolong menolong lebih luas. Nilai-nilai yang 
terkandung dalam besiru merke maknai dengan menolong orang tidak hanya pada masyarakat yang ada di daerahnya atau masyarakat yang datang ke daerah Sembalun tetapi juga melakukan nilai-nilai tersebut pada masyarakat yang bahkan tidak dikenal latar belakangnya.

"Besiruan itu terwujud untuk saling membantu satu sama lain. kata lain besiruan adalah bebaturan Jadi dengan adanya besiruan atau bebaturan ini kita mampu berbuat sesuatu yang lebih dengan bekerjasama"

Selanjutnya ditegasan oleh pemuda Sembalun mas Junaedi bahwa besiru memiliki banyak makna seperti tolong menolong, gotong royong, bebaturan jika tidak ada besiruan maka tidak akan bisa terwujud gotong royong dan tidak dapat saling membantu. Lebih akrab lagi disebut sebagai bebaturan yang artinya bersaudara.

"Besiruan memiliki makna yang luas seperti mengikat persaudaraan , contohnya yang ada di mataram, di mana mereka dapat merasakan manfaat dari besiruan tersebut meskipun jauh dari kampung halaman. Kami sudah terbiasa mudah dalam beradaptasi , ketika sudah berada di luar sembalun maka pasti akan banyak memiliki teman. Ketika orang sembalun keluar dari tanah kelahirnnya maka mereka akan memabawa manfaat keapda orang lain misalnya anak-anak sembalun yang ngekos di mataram maka mereka akan membawa hasil panen dari rumah mereka untuk diberikan kepada ibu kos nya , dimana hal kecil tersebut atau berbagi tersebut menjadi salah satu ciri-ciri yang ada di anak-anak sembalun"

Dalam Besiru diandang membentuk kepribadian masyarakat yang ramah sehingga meskipun diaman saja, kepribadian ramah dan interaksi sosial yang baik membentuk masyarakat sembalun dapat bergaul dengan masyarakat lain sehingga disebut sebagai bebaturan yang berarti bersaudara artinya setiap orang dianggap saudara yang harus dibantu ketika terjadi masalah atau mendapat kesusahan.

Perbedaan makna yang muncul dalam persepsi masyarakat diakibatkan oleh perbedaan agen sosialisai yang terbentuk dalam masyarakat. Pemuda memiliki makna yang luas dan pemahaman yang jauh tentang besiru karena pendidikan yang tinggi dan membentuk pengetahuan-pengetahuan dengan cara berfikir yang luas sehingga makna besiru juga berbeda

Pada Proses internalisasi masyarakat mulai memaknai secara subyetif tindakan Besiru sehingga muncul suatu tindakan inter-subyektif dimana ralitas obyektif dimaknai kembali oleh masyarakat. Pemaknaan kembali ini membentuk suatu perubahan seperti halnya pada budaya Besiru yang memaknai besiru lebih luas lagi.

Skema di atas menjelaskan bahwa terdapat tiga proses dialektika dalam teori Peter L. Berger, yaitu eksternalisasi, obyektivasi dan internalisasi. Proses pertama yakni eksternalisasi Pencurahan diri terhadap yang berdasarkan pemahaman dan pengetahuan kemudian proses ke dua yakni obyektivasi untuk pemahaman bersama yang menjadi realitas obyektif dalam masyarakat selanjutnya proses yang terakhir yakni internalisasi, agen sosialisasi serta pemaknaan individu terhadap besiru. 
Skema 1.1

Alur Berfikir Teori

Pemahaman bersama yang menjadi realitas obyektif dalam masyarakat

Obyectivasi



Budaya Besiru



Pencurahan diri terhadap yang

berdasarkan pemahaman dan

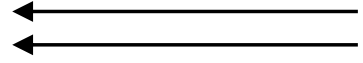

Agen sosialisasi serta Pemaknaan pengetahuan individu terhadap besiru

\section{KESIMPULAN}

Besiru merupakan budaya yang terdapat dalam masyarakat sasak khususnya di daerah Sembalun Bumbung kecamatana Sembalun. Besiru ini bisa diartikan tolong menolong, atau saing balas dalam kebaikan. Pada awalnya Besiru muncul karena adanya sistem pertanian yang saling membantu, baik dari membajak sawah, menanam hingga panen kemudian saling memberikan hasil panen. Hal tersebut yang membuat masyarakat saling membantu satu sama lain sehingga saling mencukupi satu sama lain. Dalam bidang budaya juga Besiru terlihat dalam acara penikaha, kelahiran maupun kematian dan haji. Pada kegiatan tersebut masyarakat saling membantu untuk menyiapkan semua peralatan maupun perlengkapan yang dibutuhkan, dan saling menyumbang miliknya satu sama lain.

Pandangan Peter L. Berger, pada konstruksi sosial melihat Besiru sebagai sebuah konstruksi sosial yang terbentuk dengan 3 tahap yaitu eksternalisasi, objectivasi dan internalisasi. Proses pertama yakni eksternalisasi Pencurahan diri terhadap yang berdasarkan pemahaman dan pengetahuan kemudian proses ke dua yakni obyektivasi untuk pemahaman bersama yang menjadi realitas obyektif dalam masyarakat selanjutnya proses yang terakhir yakni internalisasi, agen sosialisasi serta pemaknaan individu terhadap besiru. Sehingga pada 
konstruksi sosial Berger yang menunjukkan bahwa besiru menjadi suatu kondisi sosial yang turun temurun dan dilestarikan karena terus berputar melalui 3 tahap tersebut

\section{Rekomendasi}

Berdasarkan simpulan di atas, maka peneliti memberikan beberapa rekomendasi antara lain (1) Bagi Peneliti selanjutnya diharapkan dapat menyempurnakan pengetahuan dan keterampilan peneliti mengenai konstruksi sosial solidaritas besiru pada masyarakat Lombok dan dapat menjadi salah satu dasar, acuan, dan rekomendasi untuk mengembangkan penelitian selanjutnya. (2) Bagi Pemerintah diharapakn dapat dijadikan referensi dalam mengambil keputusan melalui penemuan data yang akan didaptkan untuk membangun Lombok kembali pasca gempa. (3) Bagi masyarakat Diharapkan dapat memberikan inspirasi kepada masyarakat lain untuk terus melestarikan budaya dan kearifan lokal yang dimiliki.

\section{DAFTAR PUSTAKA}

Hamidah (2002).Perbedaan Kepekaan Sosial Ditinjau Berdasarkan Persepsi Remaja terhadap Pola Asuh Orang Tua Pada Remaja di Jawa Timur. Isnane vol. 4 no.3 desember 2002.

Lexi J. Moleong. 2001. Metedologi Penelitian Kualitatif. Bandung : Remaja Rosada Karya.

Ritzer, George dan Douglas J. Goodman. 2004 Teori Sosiologi Modern. Jakarta Prenada Media,

Setiadi, E dan Kolip, U. 2011. Pengantar Sosiologi: Pemahaman dFakta dan Gejala Permasalahan Sosial, Teori, Aplikasi, dan Pemecahannya. Jakarta Prenada Media Group

Sugiyono. 2007. Metode Penelitian Kuantitatif Kualitatif dan R\&D. Bandung: Alfabeta 